\title{
The Cultivation of Comprehensive Quality of College Students
}

\author{
Hui Zhang, Hui Li
}

Department of Electrical Engineering, North China Electric Power University, Baoding, China

\author{
Keywords: College Students, Comprehensive quality, Higher education
}

\begin{abstract}
In the new period of Socialist Construction, the demand for high-quality talents is very urgent. colleges and universities are the main channel to transport high-quality talents to the society, so the higher education should attach great importance to improve the comprehensive quality of college students, and strive to cultivate students' ability of sustainable development. Higher education should put the cultivation and improvement of the comprehensive quality of college students in the first place, and promote the all-round development of students' comprehensive quality, so as to adapt the growing needs of talents in the society. This paper discusses the importance, requirements, the approaches and the methods to cultivate the comprehensive quality of college students.
\end{abstract}

\section{Introduction}

The improvement of the comprehensive quality of college students has always been the focus in the higher education, and how to improve the comprehensive quality of college students and cultivate students' ability of sustainable development is related to whether they can cultivate high-quality talents and whether the Socialist Construction can be carried out smoothly. The higher education should focus on the all-round development of the comprehensive quality of students and develop students into high-quality talents who have a wide range of knowledge and ability. Therefore, higher education should put the comprehensive cultivation and improvement of the overall quality of people first, to adapt to the growing needs of society.

\section{The Importance and basic Requirements of Cultivating College Students' Comprehensive Quality}

Importance. In the modern society with rapid development of science and technology, the combination of higher education and society is more closely. Higher education needs to pay more attention to the quality of talents and high-level talents. This also demonstrates the decisive role of talents in the Socialist Construction with Chinese Characteristics. The Socialist Modernization requires high-quality talents, so it is very important to develop education and strengthen the training of high-level talents. The high-quality reflects in three aspects, ideological and moral quality, scientific and cultural knowledge quality and ability quality. It can be seen clearly that higher education is of great significance in enhancing the comprehensive quality of college students.

Basic Requirements. First, high-level ideology and morality. The ideological and moral qualities of college students are closely linked with the cause of the Socialist Modernization. Political reliability and ideological and moral loftiness are the first quality requirements among modern talents, which are related to the sustainable development of our country. Therefore, graduated students must be of high quality and dedication, so as to truly serve the Socialism Construction with Chinese characteristics and become useful talents.

Second, solid professional foundation and broad knowledge. With the rapid development of science and technology, science and technology show a tendency of high-degree integration. In order to meet the needs of the society, border disciplines gradually appear and attract our attention in the higher education, which also make the division between social science and natural science blurred. Therefore, the requirements of knowledge and culture are also getting higher and higher in the society, the modern society requires college students have a reasonable knowledge structure, not only can meet the professional needs, but also has its own Special feature, not only have solid 
professional knowledge, but also can grasp the latest scientific and technological development of the dynamic frontier knowledge. Only in this way can we grasp the pulse of the times and promote the social development.

Third, the comprehensive ability. The modern society is a competitive society, and its requirements of talents on the ability transforms from the past single to multiple, complex and integrated. In the view of long run, the competition for talented people will become the center of competition. The society not only pays attention to the knowledge quality of talents, but also emphasizes the ability of talents. It involves many aspects, such as communicative ability, expressive ability and thinking ability. Therefore, colleges and universities not only need to make efforts to help students to learn professional knowledge, but also focus on the comprehensive ability of students.

\section{Measures to Strengthen the Cultivation of College Students' Comprehensive Quality}

Strengthen the Ideological and Moral Education. Strengthen the ideological and moral education is one of the most important contents of higher education. By strengthening the ideological and moral education, can students establish a correct outlook on life and morality, and establish a firm and correct political direction. To strengthen the ideological and moral education of college students, we must adhere to permeating the Chinese traditional virtues to the quality education, so as to cultivate the noble morality of college students. The Chinese traditional culture embodies the spirit of unity and forging ahead, reflecting the great spirit and temperament of the Chinese nation's unremitting self-improvement. Using this national traditional spirit to educate and guide students to enhance their national self-esteem, self-confidence, self-reliance, so as to meet the needs of the times and cultivate a new national spirit. In addition, the construction of spiritual civilization on campus has a subtle effect on the ideological and moral education of college students. Colleges and universities should strengthen the construction of campus spiritual civilization, promote scientific theory and advanced culture actively, and encourage campus healthy trends.

Cultivate Good Psychological Quality. Because of college students are in the transition period from naive to maturity, it is easy to have various psychological problems, which will affect the students' physical and mental health, and the formation of correct outlook of life. Universities and colleges should pay attention to the psychological quality of college students in the following aspects: First, social psychological education. Colleges should educate students to adapt to society and constantly adjust themselves on the way to improve their own quality, so as to meet future challenges; Second, personality psychological education. The determination of self-worth, the shaping of lively character and the cultivation of accurate judgment and broad interest, are all required to improve through education; Third, interpersonal communication education. Higher education should also guide students to learn how to get along with others, establish a good teacher-student relationship, and create the best teaching atmosphere, so that there can maximize the development of the potential of students, and make their creativity and adaptability get the most effective stimulation.

Optimize the Curriculum System and the Content of Courses. Higher education should according to the needs of the society to set the professions and curriculums and have a clear pertinence. Meanwhile, universities and colleges should promote the subjective position of students vigorously and meet their individual development. Universities and colleges need to explore the reform of curriculum system actively, and make a positive adjustment in the teaching objectives and teaching content, so that students can select courses independently according to interests and social requirements. In terms of teaching objectives, transform the focus from knowledge-teaching to the cultivation of students' ability. In terms of curriculum system, structure the curriculum so as to build a scientific and rational personnel training program, and lay a foundation for the infiltration of scientific knowledge and human knowledge. In terms of teaching content, it should emphasize the continuous updating and practicality of the content, so that the teaching content and individual needs can be linked closely.

Cultivate Innovation Ability. The implementation of the comprehensive cultivation of colleges' 
innovation ability is the core content in the contemporary higher education and the leading spirit in the field of knowledge-based economy education. The quality education is aimed at training creative talents, because creative talents have a strong creative thinking and ability, and have the courage to practice, and have a strong adaptability. They can survive and develop especially in adversity, so colleges and universities should pay special attention to the cultivation of college Students' ability of innovation. First, colleges and universities should strengthen the construction of training base about the practical innovation, perfect the construction of the campus innovative base, expand the development among the firms, universities and research institutes; second, in term of the design of teaching management system, it is necessary for colleges and universities to consider the cultivation of students' innovation consciousness, innovation spirit and innovation ability fully, promote the coordinating development among students' knowledge.

Strengthen the Training of Practical Ability. Practical activities can be described as an important way to improve the comprehensive quality of college students. Colleges and universities should pay attention to cultivating students' practical ability and innovative spirit. Practical ability mainly refers to the ability of scientific practice and social practice, scientific practice is mainly through scientific research activities to increase students' opportunities for scientific practice, improve they ability to analyze and solve problems. Social practice is mainly helping college students to understand the society and evaluate themselves objectively through social investigation and social services, social practice is an important process of college students to adapt to society. Colleges and universities should actively carry out a variety of practical activities to help students combine the knowledge and the practice to meet the requirements of the competitive society. Practical activities can expand the space of humanistic education, and promote the integration of scientific knowledge and humanistic knowledge.

\section{Discussion}

As is discussed above, the education of institutions of higher learning should attach great importance to improve the comprehensive quality of college students, and strive to develop students' ability of sustainable development. The higher education should make effort to promote the development of students' individual quality and comprehensive quality, achieve the all-round development, cultivate students' noble personality. By this way, the requirements of talents in the society can be meet, and the pace of building a harmonious society can be accelerated.

\section{Conclusions}

Facing the difficult task brought by the new century and the advanced science and technology, we must deeply understand the importance of cultivating the comprehensive quality of college students, and strive to perfect the personnel training mechanism in colleges and universities. Compared with any other institution, the role of colleges and universities in the cultivation of talents and the dissemination of knowledge is irreplaceable. Therefore, colleges and universities should be take the cultivation of the comprehensive quality of college students as their mission and responsibility, and actively guide students to establish a correct outlook on the world, life, values.

\section{Acknowledgements}

This research is supported bythe teaching reform project of North China Electric Power University.

\section{References}

[1] Qian ZHANG, Ling WANG, Ying MA. Directors of Comprehensive Quality System of College Students in China: Based on BP Neural Network [J]. Management Science and Engineering, 2013,73: p.99-102.

[2] Zhuo ZHONG. To Strengthen Campus Cultural Construction in Institutions of Science and 
Engineering to Promote Ideological and Political Education of College Students [J]. Higher Education of Social Science,2015,82:p.25-28.

[3] YingLi, Billie J. Lindsey, Xiaoqin Yin, Bingqing Wang. Chinese college students' health-promotion practices: a preliminary study [J]. International Journal of Health Promotion and Education,2014,523: p.131-143.

[4] ZhenhuiXu, Hanlin Chen. Research and Practice on Basic Composition and Cultivation Pattern of College Students’ Innovative Ability [J]. International Education Studies,2010, 32.

[5] ShimingHao, Liben Li, Xinzhong Li, Xiaoyang Gong. The Training Mode Reform of Physical Practical Talents Emphasizing on Innovation Ability [J]. Creative Education, 2014, 0501:p.1-3. 